\title{
Interactions between oceanography, ecology and fishery biology of the ommastrephid squid Martialia hyadesi in the South Atlantic
}

\author{
A. F. González ${ }^{1, *}$, P. N. Trathan ${ }^{1}$, C. Yau ${ }^{2}$, P. G. Rodhouse ${ }^{1, * *}$ \\ ${ }^{1}$ British Antarctic Survey, Natural Environment Research Council, High Cross, Madingley Road, Cambridge CB3 0ET, \\ United Kingdom \\ ${ }^{2}$ Fisheries Department, Stanley, Falkland Islands
}

\begin{abstract}
The seven star flying squid Martialia hyadesi is an oceanic slope ommastrephid with a circumpolar distribution associated with the Antarctic Polar Frontal Zone (APFZ) and is a minor, variable catch in the South Atlantic Illex argentinus fishery. There have been occasional unusually large catches of $M$. hyadesi, the latest being in 1995. Because of the importance of understanding the influence of the physical environment on fisheries for oceanic squid, and interest in developing a new fishery for $M$. hyadesi in the CCAMLR area, we examined specimens and data from the 1995 season and analysed $10 \mathrm{yr}$ fisheries and remotely sensed oceanographic data sets from the area. The 1995 data show that $M$. hyadesi remains in the cool APFZ waters of the Falkland Current where it preys on oceanic fish and crustaceans and its distribution rarely extends over the Patagonian Shelf. The squid exploited by the fishery in 1995 were 6 to 12 mo old; females were immature but some males were fully mature. A remotely sensed sea surface temperature (SST) image revealed mesoscale features at the shelf break front between Patagonian Shelf water and APFZ water where the squid were caught. The appearance of $M$. hyadesi in the fishery over the last decade, including 1995, has been related to SST anomalies. Teleconnections probably exist between these anomalies, El Niño/Southern Oscillation (ENSO) events in the Pacific and sub-decadal oceanographic instability in the Antarctic. Squid are short-lived and populations are likely to be able to respond rapidly to environmental change. However, it is not clear at what stage in the life cycle of $M$. hyadesi these oceanographic events exert their effect. We propose 2 alternative, but not mutually exclusive, hypotheses. Warm events prior to the appearance of $M$. hyadesi may favour reproductive success of the parent generation giving rise to a strong recruitment, or alternatively this cool water species may extend its range to the edge of the Patagonian Shelf early in the development of cold oceanographic events. In either case oceanographic effects are probably mediated via the squid's prey.
\end{abstract}

KEY WORDS: Martialia hyadesi - Oceanography · Ecology Fishery biology $\cdot$ South Atlantic

\section{INTRODUCTION}

The squid fishery in the southwest Atlantic is domjnated by the Argentine shortfin squid Illex argentinus which is widely distributed over the Patagonian Shelf. There is also a relatively minor and variable fishery

\footnotetext{
- Present address: Instituto de Investigaciones Marinas, Consejo Superior de Investigaciones Científicas, Eduardo Cabello 6, E-36208 Vigo, Spain

- Addressee for correspondence

E-mail:pgkr@pcmail.nerc-bas.ac.uk
}

for the seven star flying squid Martialia hyadesi, an oceanic shelf species whose distribution extends from the open ocean in the Antarctic Polar Frontal Zone (APFZ) to the Patagonian Shelf edge (Rodhouse 1991). The $M$. hyadesi catch is small relative to the total stock (Rodhouse et al. 1993, Rodhouse in press) and small in comparison with the size of the 1 . argentinus catch. It is caught by vessels primarily targeting $I$ argentinus. $M$. hyadesi catch rate probably reflects environmentally driven variability in the stock more accurately than the catch rate of $I$. argentinus which is fully exploited, or overexploited. The I. argentinus stock is heavily influ- 
enced by differences in fishing effort, and catches are therefore subject to the effects of economic, social and political factors.

Martialia hyadesi occupies an important position in the trophic web of the Southern Ocean ecosystem (Rodhouse \& White 1995) and it has been estimated that consumption by higher predators in the Scotia Sea amounts to at least $326000 \mathrm{t} \mathrm{yr}^{-1}$ (Rodhouse et al. 1993). Dietary analysis of $M$. hyadesi from samples obtained in the APFZ in the Scotia Sea showed that $M$. hyadesi is an opportunist predator feeding on a range of prey including mesopelagic fish, crustaceans and cephalopods (Rodhouse et al. 1992b). Feeding concentrations have been located in mesoscale oceanographic features at the Antarctic Polar Front (APF) (Rodhouse et al. 1996). The lifespan of $M$. hyadesi is short, although it may be more than 1 yr (Rodhouse et al. 1994), and in common with other squid $M$. hyadesi is almost certainly semelparous.

Only relativcly small quantities of Martialia hyadesi have been caught in the Falkland Islands Conservation Zone since 1987, when it was established. However, a catch of about 26000 t of $M$. hyadesi was reported from the area in 1986 (Rodhouse 1991). There were no other records of high catch rates until 1995 when this study was initiated, although there was a small catch in 1990. The appearance of $M$. hyadesi in the area in 1986 was apparently associated with a change in the Falkland Current (Rodhouse 1991), which is a part of the SubAntarctic Front (SAF) (Peterson \& Whitworth 1989).

During the 1995 fishing season, on which this study is based, the majority of the Martialia hyadesi catch was taken in a restricted region to the north of the Falkland Islands, in an area close to the shelf edge. Oceanography around the Falklands Plateau is complex and different assemblages of cephalopod species are associated with the different water masses (Rodhouse et al. 1992a). In 1995 catches were taken close to the main flow of the Falkland Current which is highly dynamic (Legeckis \& Gordon 1982, Davis et al. 1996) with temporally variable eddies and fronts. Variability in the Falkland Current is related to variability in the Brazil Current (Legeckis \& Gordon 1982) and is complicated by interannual variability in the proximity of both currents to the Patagonian Shelf (Olson et al. 1988, Garzoli \& Garrafo 1989). Further complexity in the region also arises from interannual variability in the positions of the APF and the SAF south of the Falkland Islands; for example Ikeda et al. (1989) reported that both fronts were in different positions in each of the 4 years that they studied the area, with both positions varying by as much as $160 \mathrm{~km}$.

Given the importance of understanding the influence of the physical environment on variability in squid fisheries, and the wider interest in developing a new fishery for Martialia hyadesi in the Commission for the Conservation of Antarctic Marine Living Resources (CCAMLR) area (Rodhouse in press), we have examined the biology of $M$. hyadesi on the Patagonian shelf edge following the large catch in 1995. The objectives of this paper are to characterise the demography and trophic ecology of the $M$. hyadesi population. on the Patagonian Shelf edge in 1995 when there were large numbers in the fishery, to describe the distribution of the population in relation to mesoscale oceanographic processes in the area at the time, to contrast this with the distribution of the Hlex argentinus stock on the southern Patagonian Shelf, and to present a causal hypothesis for the variability in catch rate of $M$. hyadesi in a fishery driven by variability in the physical environment.

\section{MATERIAL AND METHODS}

Sampling methods. Twelve samples of Martialia hyadesi were collected aboard 6 Korean registered squid jiggers operating in the Falklands Interim Conservation and Management Zone (FICZ) and Falklands Outer Conservation Zone (FOCZ) between 10 and 23 May 1995. The vessels were of similar size (average total length $55 \mathrm{~m} ; 650 \mathrm{GRT}$ ). Fishing was at night with lights between 80 and $120 \mathrm{~m}$ depth targeting marks on fish-finding echosounders. Samples were deep-frozen. $\left(-20^{\circ} \mathrm{C}\right)$ and shipped to the British Antarctic Survey in Cambridge, UK.

Data on sea surface temperature (SST), water depth, total catch per drift and catch per unit effort (CPUE) were also recorded by Falkland Islands Government (FIG) observers aboard squid jiggers in the same fleet between 24 April and 23 May 1995.

A small sample of Martialia hyadesi ( $\mathrm{n}=48$ ) was also taken from a by-catch in the trawled Loligo gahi fishery near the $200 \mathrm{~m}$ isobath $\left(50^{\circ} 55^{\prime} \mathrm{S}, 56^{\circ} 51^{\prime} \mathrm{W}\right.$ ) on the edge of the shelf to the northeast of the Falkland Islands in August 1995.

Data on ommastrephid squid catches in the Falkland Islands Conservation Zones (FOCZ and FICZ) for the last 10 yr were provided by the FIG, Japanese catches of Martialia hyadesi were provided by the National Research Institute for Far Seas Fisheries (NRIFSF), Shimizu, Japan, and total catches of $M$. hyadesi reported to the UN Fisheries and Agriculture Organisation (FAO) were obtained from the current yearbook (FAO 1994). Prior to 1987 the Japanese data were compiled by commercial operators and subsequently they have been prepared by NRIFSF.

Treatment of samples. A total of 336 specimens (232 females and 104 males) was analysed. Data were collected on sex and maturity stage according to Lipinski (1979). Mantle length (ML) of all squid was measured to 
$1 \mathrm{~mm}$ and body mass (BM) determined to $0.1 \mathrm{~g}$. Frequency distributions of size and maturity stage were calculated as a percentage of the total number of specimens, treating male and female data separately.

Treatment of statoliths. A sample of 110 pairs of statoliths (35 males and 75 females) were dissected from the heads according to Dawe \& Natsukari (1991) and stored in ethanol $(96 \%)$. The right statolith of each pair, when possible, was mounted in Crystal Bond Resin ${ }^{\oplus}$. Both sides of the statolith were ground to reveal daily growth rings using $30 \mu \mathrm{m}$ carborundum paper for grinding and $3 \mu \mathrm{m}$ for polishing. An optical microscope $(\times 400)$ with an image analysis system was used for counting the number of growth rings. Image analysis was used for both counting and estimating increment numbers in regions of the statolith where the growth rings were obliterated or difficult to read. Where more than $15 \%$ of the rings were obliterated the statolith was rejected.

Frequency distribution of back-calculated hatch date was calculated as a percentage of the total number of specimens with male and female data pooled.

Diet analysis. Stomach contents were weighed and separated into fish, crustaceans and cephalopods. Otoliths, cephalopod beaks and crustacean integument were identified to the lowest possible taxonomic level and measured. Fish were identified from otoliths by reference to Hecht (1987), Williams \& McEldowney (1990) and Reid (1996). Crustacean identification followed Brinton \& Antezana (1981) and Kane (1966). Cephalopods were identified from beaks (Clarke 1986) and suckers (Rodhouse \& Yeatman 1990). Prey were also identified by comparison with the reference collection of fish, crustaceans and cephalopods held at the British Antarctic Survey. Size of fish and cephalopod prey was back-calculated using equations relating body size to otolith and beak size respectively (Rodhouse \& Yeatman 1990, Reid 1996). Where no recognisable parts were found, remains were removed and classified as unidentified crustacean or fish on the basis of scales, bones, fragments of integument, etc. The indices used for diet description are as follows:

(1) Occurrence index:

$$
\mathrm{CI}=100 \times \frac{\text { no. of stomachs with prey type }}{\text { total no. of stomachs containing prey }}
$$

Using this index each stomach is counted as many times as the number of prey types it contained.

(2) Frequency of occurrence:

$$
F=100 \times \frac{\text { no. of stomachs with prey type }}{\text { total no. of stomachs }}
$$

Oceanographic data. A remotely sensed, infrared image of the Patagonian Shelf and oceanic region around the Falklands Islands, at $09: 30 \mathrm{~h} \mathrm{Z}$ on 21 April
1995, was selected from the ARIES (Antarctic Reception of Imagery for Environmental Studies) database to illustrate the surface features of mesoscale oceanographic processes in the region of the fishery.

One of the objectives of the study was to explore whether teleconnections existed between the oceanographic and biological variability observed in the Martialia hyadesi fishery in the South Atlantic, and variability elsewhere in the southern hemisphere. For example it has been suggested that there may be associations between El Niño/Southern Oscillation (ENSO) events in the Pacific and historical variability in the whale fishery and krill abundance (Croxall et al. 1988, Priddle et al. 1988) at South Georgia.

Thus a large-scale SST data set (Reynolds \& Smith 1994) was used to integrate mesoscale variability and identify anomalous periods. The data cover the period November 1981 to July 1996, which includes the period during which the Falkland Islands squid fishery has been formally managed (1987 to 1996) and the preceding period during which the fishery was unlicensed but for which some fishery data are available (1985 to 1987). Reynolds \& Smith (1994) described the National Oceanic and Atmospheric Administration (NOAA) operational global SST analyses. Seven day in situ ship and buoy SST data and satellite SST data were used to produce daily, weekly and monthly grids by optimum interpolation (OI) at a resolution of $1^{\circ}$ latitude by $1^{\circ}$ longitude. The monthly grids from the SST Ol covering the period November 1981 to July 1996 have been loaded into a marine Geographical Information System (GIS) (Trathan et al. 1993). The GIS, using Arc/Info 7.0.4 (ESRI), was used to select SST OI data around the Falkland Islands.

In order to select grid cells that integrate the local mesoscale variability (but which are located away from land areas and away from areas where the bathymetry changes), the historical SST OI data set was examined in Arc/Plot, a component of Arc/Info. A single grid cell $\left(49^{\circ} 30^{\prime} \mathrm{S}, 59^{\circ} 30^{\prime} \mathrm{W}\right)$, where water depth was approximately $200 \mathrm{~m}$ and SST relatively homogeneous, was taken as representative of the shelf north of the Falkland Islands (position arrowed in Fig. 9b).

\section{RESULTS}

\section{Historical catch data for Martialia hyadesi in the southwest Atlantic}

Reported catches for Martialia hyadesi are shown in Fig. 1b. These clearly indicate that in some years substantial quantities were caught outside the Falkland 

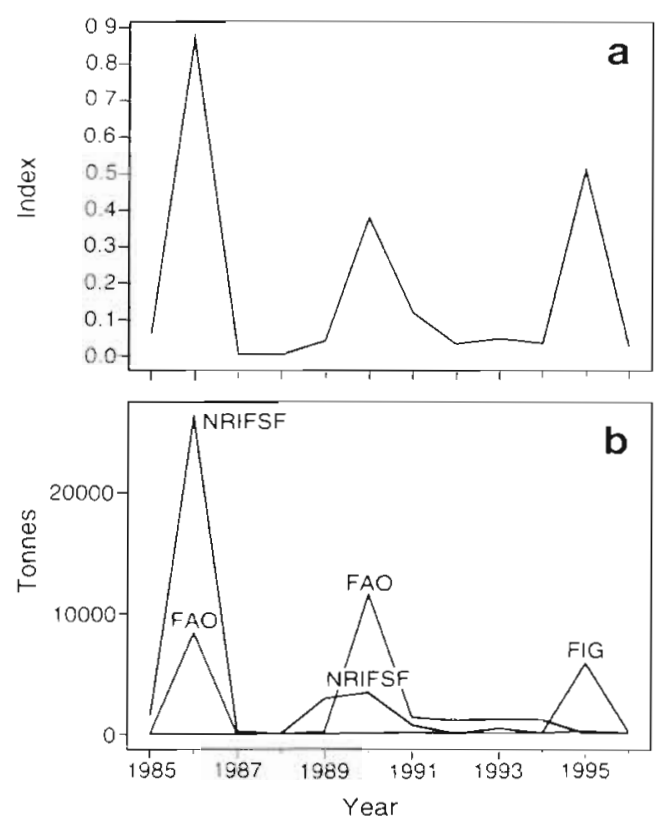

Fig. 1 Martialia hyadesi. (a) Average index of catches (see text for details). (b) Annual catch between 1985 and 1996 as reported to the Falkland Islands Government (FIG) Fisheries Department, Stanley, National Research Institute for Far Seas Fisheries (NRIFSF), Shimizu, Japan and the UN Fisheries and Agriculture Organisation (FAO), Rome
Islands Conservation Zones and also that FAO statistics do not include all catches. Taken together, the data provide the best available description of the fishery. Fig. 1a shows the total catch for each year expressed as a mean index in which the maximum catch in a series is given as unity and the catch for other years expressed as a proportion of the maximum. It indicates, despite the vagaries of the data, that 'Martialia hyadesi events' occurred in 1986 (before FIG records began), 1990 and 1995.

\section{Distribution of Martialia hyadesi and} Illex argentinus in 1995: depth/temperature relations

Spatial distribution of the Martialia hyadesi fishery between 4 and 19 May 1995 in the FICZ/FOCZ is shown in Fig. 2 together with the distribution of the Illex argentinus fishery between the start of the season and 19 May. $M$. hyadesi catches were made towards the end of the $I$. argentinus season. Highest densities of M. hyadesi were found in the FOCZ outside the $200 \mathrm{~m}$ isobath to the north of the Falkland Islands (Fig. 2a). Highest densities of $I$. argentinus during the same period were in the FICZ on the shelf to the northwest of the Falkland Islands (Fig. 2b).
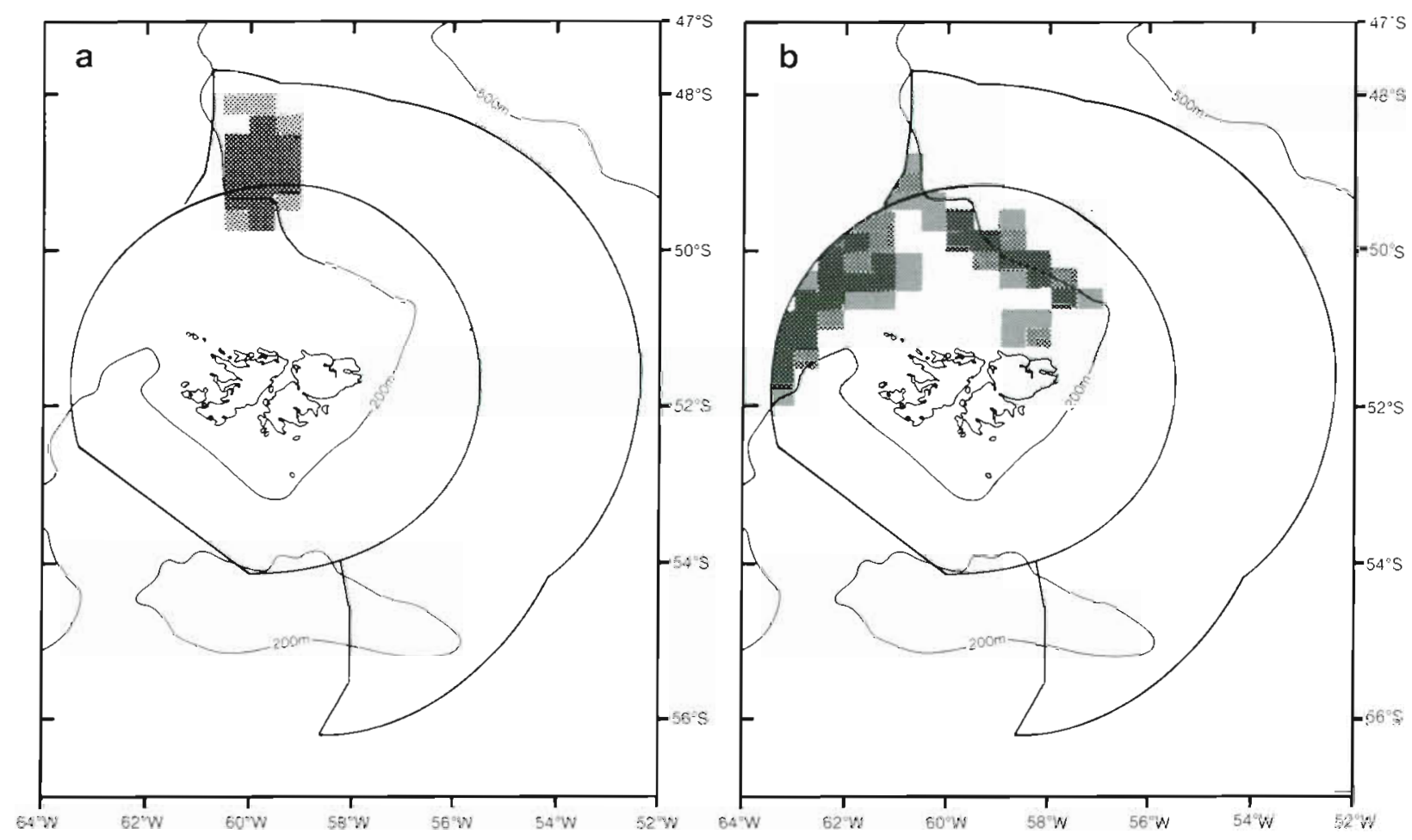

Fig. 2. Distribution of catches of (a) Martialia hyadesi (4 to 19 May 1995) and (b) Illex argentinus (1 February to 19 May 1995 ) in the Falklands Interim Conservation and Management Zone (FICZ) and Falklands Outer Conservation Zone (FOCZ). Isobaths for 200 and $500 \mathrm{~m}$ are shown; FICZ and FOCZ indicated by thick lines; density of shading indicates catch density 
The relationship between seabed depth and catch per unit of effort (CPUE) for Illex argentinus and Martialia hyadesi caught by a jigger near the Patagonian Shelf during the period 24 April to 4 May 1995 (FIG observer R. Coggan) is shown in Fig. 3. This clearly illustrates a separation in distribution between the 2 ommastrephid species, although very small numbers of each species overlap. I argentinus was mostly caught over depths of about $250 \mathrm{~m}$, on the Patagonian shelf edge. The maximum CPUE for $I$. argentinus was $29.3 \mathrm{~kg} \mathrm{~min}^{-1}$ vessel $^{-1}$ over a depth of $260 \mathrm{~m}$. No substantial catches of $I$. argentinus were taken over depths $>260 \mathrm{~m}$. In contrast very few $M$. hyadesi were caught over depths $<230 \mathrm{~m}$. Highest values for CPUE recorded for $M$. hyadesi were over depths $>270 \mathrm{~m}$, off the edge of the continental shelf. The maximum CPUE for $M$. hyadesi was $49.6 \mathrm{~kg} \mathrm{~min}^{-1}$ vessel $\mathrm{l}^{-1}$ over a depth of $410 \mathrm{~m}$.

The relationship between SST, depth and CPUE for Martialia hyadesi determined over $6 \mathrm{~d}$ between 12 and 19 May, on 6 different jiggers (FIG observer C. Yau) is shown in Fig. 4. CPUE was inversely related to SST, with maximum catch rates in areas where SST was 7.5 to $8.0^{\circ} \mathrm{C}$ (over water depths $>500 \mathrm{~m}$ ).

\section{Population structure in 1995}

\section{Size}

Size frequency distributions for males and females are shown in Fig. 5. Both sexes had unimodal distributions; mean mantle lengths (ML) for males and females were $285 \pm 31$ (SD) $\mathrm{mm}$ and $302 \pm 31$ (SD) mm respectively. The male and female modes were 290 and $310 \mathrm{~mm}$ ML respectively. Male mantle lengths were 187 to $334 \mathrm{~mm}$, with a total body mass (BM) of 92 to

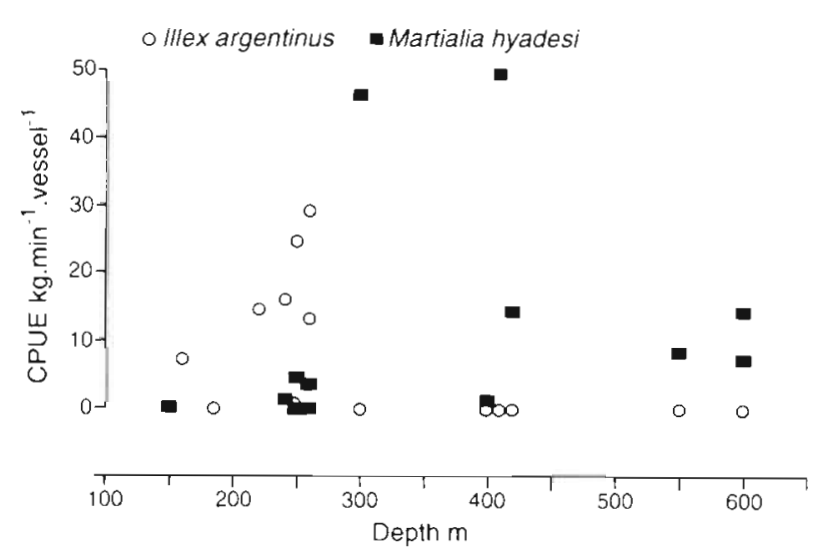

Fig. 3. Martialia hyadesi and Illex argentinus. Relationship between catch per unit effort (CPUE) and depth recorded on a single squid jigger between 24 April and 4 May

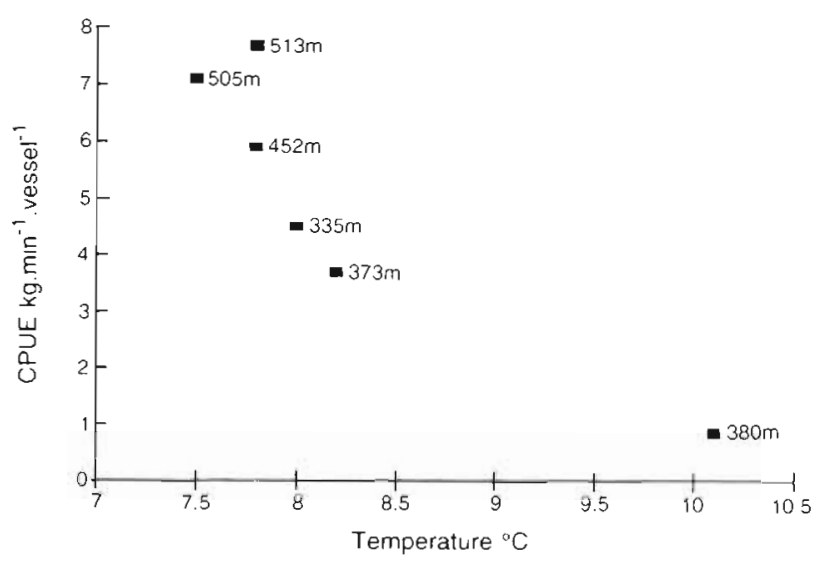

Fig. 4. Martialia hyadesi. Relationship between catch per unit effort (CPUE), sea surface temperature and depth recorded on 6 different squid jiggers between 12 and 19 May

754 g. Females were larger, ranging from 185 to $358 \mathrm{~mm} \mathrm{ML}$ with a total BM of 358 to $817 \mathrm{~g}$.

Regression equations for the relationship between $\mathrm{ML}$ in $\mathrm{mm}$ and $\mathrm{BM}$ in $\mathrm{g}$ for males and females were as follows:

$\begin{array}{llll}\text { Males: } & \ln B M=3.408 \ln M L-13.294 & \left(r^{2}=0.97 ;\right. & n=104) \\ \text { Females: } & \ln B M=3.280 \ln M L-12.609 & \left(r^{2}=0.96 ;\right. & n=232)\end{array}$

Both sexes of Martialia hyadesi showed significant $(p<0.005)$ positive allometry (i.e. slope, $b>3)$. Males had higher BM than females for a given ML. Body mass of $M$. hyadesi is substantially less than in Illex argentinus of equivalent mantle length (Rodhouse \& Hatfield 1990). From the equations, male and female M. hyadesi of ML $300 \mathrm{~mm}$ have a body mass of 486 and $445 \mathrm{~g}$ respectively whereas male and female $I$. argentinus of the same ML have a body mass of 804 and $598 \mathrm{~g}$ respectively. This is because $M$. hyadesi mature at a

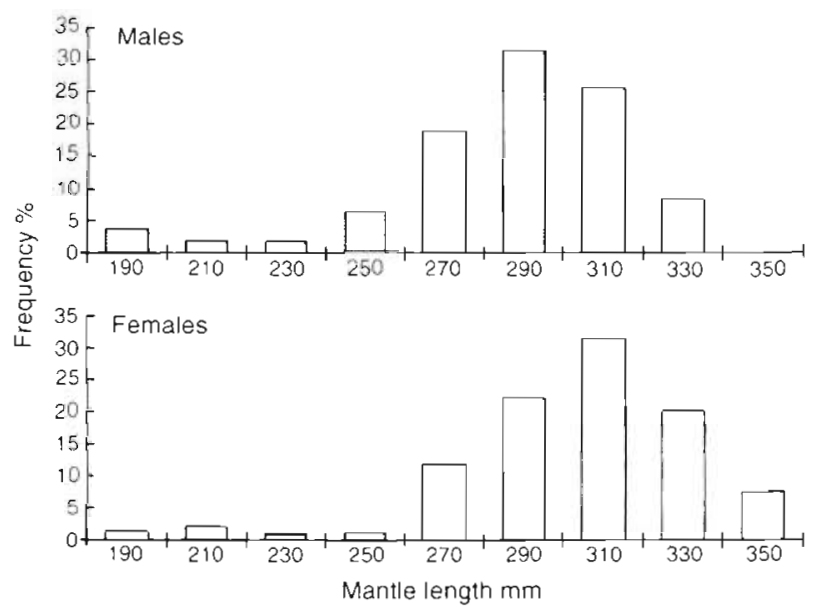

Fig. 5. Martialia hyadesi. Mantle length frequency distributions of males and females from the 1995 fishery 


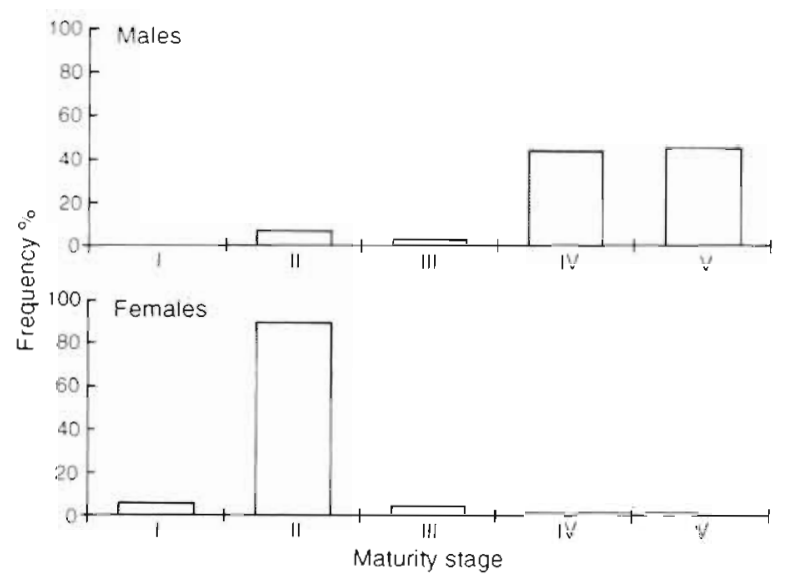

Fig. 6. Martialia hyadesi. Proportion of each maturity stage of males and females from the 1995 fishery

larger size (and age) so they are less mature, and hence have lower mass, at a given ML.

\section{Sex ratio and maturity stages}

Females were approximately twice as abundant in the catch as males ( $\mathrm{M}: \mathrm{F}=0.48: 1$ ). A large proportion (>97\%) of males were maturing or mature (stages IV or $\mathrm{V})$ while females were mostly immature. A few females were at the preparatory stage but there were no mature females in any of the samples (Fig. 6).

Earlier observations (M. George pers. comm.) suggest the sporadic presence of mature female Martialia hyadesi in the vicinity of the Falkland Islands between 1991 and 1994. These records were made during summer and early autumn. ML of these mature females ranged between 280 and $415 \mathrm{~mm}$ ML. Two large specimens were 405 and $415 \mathrm{~mm}$ ML and weighed 1390 and $1360 \mathrm{~g}$ respectively.

\section{Age and time of hatching}

In 1995 males and females appeared in the fishery at an age of about 6 mo. The maximum age of squid examined from the catch was 330 and $357 \mathrm{~d}$ for males and females respectively (Fig. 7). Linear, exponential and power models were fitted to the data and the following equations obtained:

$$
\begin{array}{ll}
\text { Linear: } & \text { Males } M L=134.13+0.57 \mathrm{NI}\left(\mathrm{r}^{2}=0.448 ; \mathrm{n}=45\right) \\
& \text { Females } \mathrm{ML}=59.86+0.86 \mathrm{NI}\left(\mathrm{r}^{2}=0.799 ; \mathrm{n}=65\right) \\
\text { Exponential: } & \text { Males } \mathrm{ML}=159.88 \mathrm{e}^{0.0022 \mathrm{~N} I}\left(\mathrm{r}^{2}=0.449 ; \mathrm{n}=45\right) \\
& \text { Females } \mathrm{ML}=124.65 \mathrm{e}^{0.0031 \mathrm{NI}}\left(\mathrm{r}^{2}=0.763 ; \mathrm{n}=65\right) \\
\text { Power } \quad & \text { Males } \mathrm{ML}=14.04 \mathrm{NI} \mathrm{I}^{0.54}\left(\mathrm{r}^{2}=0.500 ; \mathrm{n}=45\right) \\
& \text { Females } \mathrm{ML}=2.47 \mathrm{NI} \mathrm{I}^{0.85}\left(\mathrm{r}^{2}=0.805 ; \mathrm{n}=65\right)
\end{array}
$$

where NI is the number of increments (or age in days)
Goodness of fit was similar for all 3 models indicating that growth at the time of the fishery was approximately linear. Depending on the model, predicted ML at age 1 yr ranged between 338 and $352 \mathrm{~mm}$ for males and 372 to $386 \mathrm{~mm}$ for females. Using the models to extrapolate $\mathrm{ML}$ at $2 \mathrm{yr}$ the predictions ranged between 460 and $492 \mathrm{~mm}$ for males and between 670 and $1198 \mathrm{~mm}$ for females. The maximum ML recorded for Martialia hyadesi is about $500 \mathrm{~mm}$ (Nesis 1987) and the observations of large females in the Falklands fishery recorded above suggest that females can reach maturity at $\mathrm{ML}>400 \mathrm{~mm}$. Extrapolating from the limited size, age and maturity range in this sample the data suggest that maximum mantle length and full maturity would be reached at, or somewhat before, 2 yr after hatching depending on sex. Assuming the squid complete their life cycle in the same season of the year that they start, there is probably some reduction in the growth rate in the latter part of the life cycle if the squid live for $2 \mathrm{yr}$. Given the scatter in the size at age data, some of the relatively large squid could reach 400 to $500 \mathrm{~mm}$ ML within 1 yr after hatching whilst the smaller squid might only reach about $300 \mathrm{~mm}$ ML after 1 yr.

Back-calculations of individual hatch dates, from age and date of capture, indicated that hatching of the squid in the 1995 samples extended from May to October 1994, i.e. during late-autumn and winter, with a maximum in August of that year (Fig. 8).

In 1995 males and females recruited into the fishery at an age of about 6 mo. The maximum age of squid caught, estimated from counts of microgrowth increments in the statolith, was 330 and 357 d for males and females respectively. Given the relatively immature reproductive status of females, these data are not inconsistent with the hypothesis that the life span of Martialia hyadesi is greater than 1 yr (Rodhouse 1991. Rodhouse et al. 1994). However, the question of the life span of $M$. hyadesi remains open and needs to be addressed by studies on mature/spawing specimens.

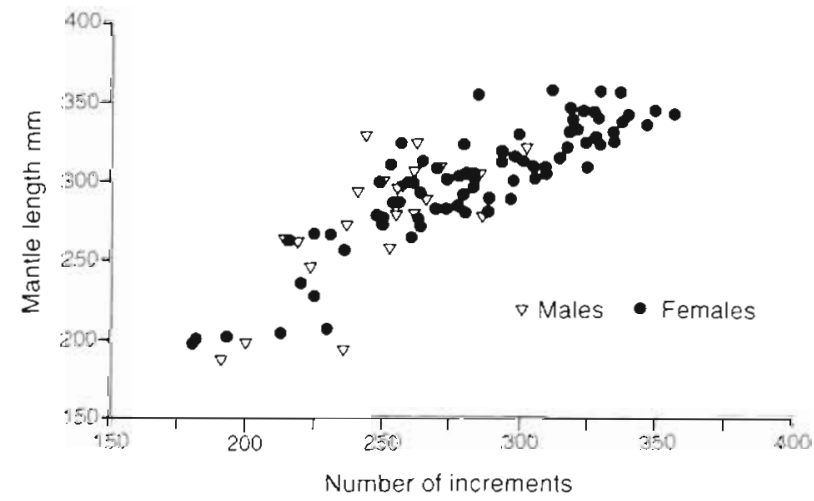

Fig. 7. Martialia hyadesi. Relationship between the number of daily microgrowth increments $(n=65)$ in the statolith and mantle length 


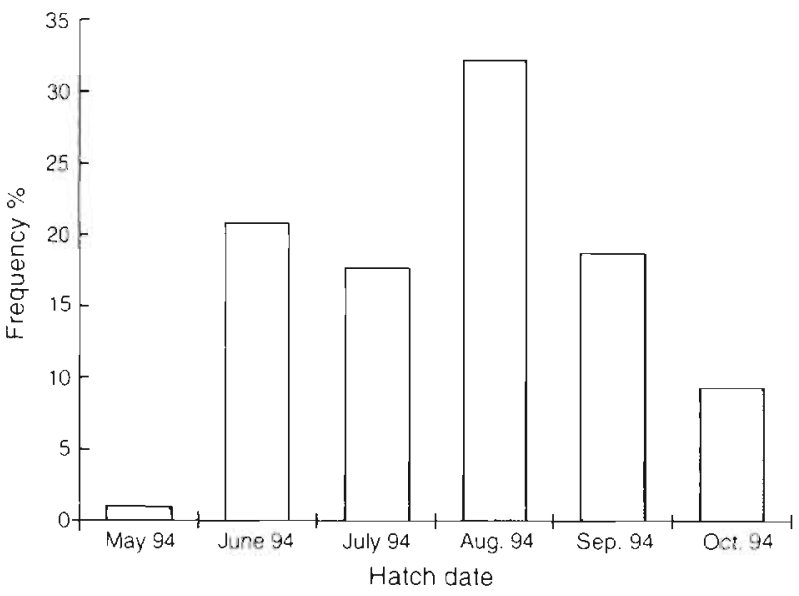

Fig. 8. Martialia hyadesi. Seasonality in hatching backcalculated from age of squid sampled from the 1995 fishery

\section{Diet of Martialia hyadesi in 1995}

A total of 9 prey species, together with unidentifiable remains from the 3 main categories, fish, crustaceans and cephalopods, were present in the stomach contents of Martialia hyadesi. The occurrence index $(\mathrm{OCI})$ and frequency of occurrence $(\mathrm{F})$ data, along with published information on the habitat of the prey species identified, are summarised in Table 1. The diet of $M$. hyadesi in the samples was mostly species of mesopelagic fish and epipelagic crustaceans characteristic of open ocean and shelf break communities.

The small sample of Martialia hyadesi collected from the Loligo gahi fishery had been feeding on crustaceans Euphausia vallentini and Themisto gaudichaudii and squid $L$. gahi. These data are not included in Table 1.

\section{Oceanography: SST and oceanographic variability}

The SST image of the region around the Falklands Islands illustrates the complex surface hydrography of the region (Fig. 9). It shows the frontal region associated with the Patagonian Shelf break and mesoscale features at the front where the Martialia hyadesi concentrations occurred in 1995. Comparison of the information in Figs. 2 \& 4 with Fig. 9 shows the squid were caught in the area where on 21 April a stream of relatively cool water $\left(\sim 7^{\circ} \mathrm{C}\right)$ was apparently flowing westwards along the shelf break north of the Falkland Islands. The image also shows the warm South Atlantic subtropical gyre to the northeast and the APF to the south. The APFZ lies in the area between the shelf break front, the subtropical gyre and the APF.

The monthly SST OI time series between November 1981 and July 1996 for the grid cell $59^{\circ} 30^{\prime} \mathrm{W}, 49^{\circ} 30^{\prime} \mathrm{S}$ and monthly anomalies (monthly SST OI time series minus average seasonal climate) are shown in Fig. 10. Extreme anomalies lie outside the pair of horizontal lines representing 2 standard deviations, i.e. $y=$ $x+2 \mathrm{SD}$ and $y=x-2 \mathrm{SD}$, where SD is the standard deviation of the anomalies.

Three periods of extreme positive anomalies are apparent: in March 1985, December 1989 to March 1990 and December 1993 to January 1994. Three periods of extreme negative anomalies are also apparent: these occurred approximately 24 or 25 mo after the positive anomalies. However, the last of these negative anomalies is not so extreme and lies above the line $y=$ $x-2 S D$; also the timing of the negative anomalies is less well defined than the positive anomalies. The Martialia hyadesi 'events' all occurred in the period

Table 1 Martialia hyadesi. Prey items in the stomach contents at Falkland Islands Conservation Zones (FICZ and FOCZ). $\mathrm{n}$ : no. of stomachs in which taxon was found; $\mathrm{OCl}$ : occurrence index; $\mathrm{F}$ : frequency of occurrence (\%); $\mathrm{O}$ : oceanic; $\mathrm{MP}$ : mesopelagic; BP: bathypelagic; EP: epipelagic. Information on habitats of prey items obtained from sources shown

\begin{tabular}{|c|c|c|c|c|c|}
\hline Prey item & $\mathrm{n}$ & $\mathrm{OCI}$ & F & Habitat & Source \\
\hline Fish (total) & $(228)$ & $(43.8)$ & $(68.1)$ & - & - \\
\hline Krefftichthys anderssoni & 136 & 26.1 & 40.6 & $O-M P$ & Williams \& McEldowney (1990) \\
\hline Protomyctophum bolini & 2 & 0.4 & 0.6 & $\mathrm{O}-\mathrm{MP}$ & Williams \& McEldowney $(1990)$ \\
\hline Protomyctophum choriodon & 17 & 3.3 & 5.1 & O-MP & Williams \& McEldowney (1990) \\
\hline Gymnoscopelus nicholsi & 45 & 8.6 & 13.4 & O-MP & Williams \& McEldowney $(1990)$ \\
\hline Notothenia squamifrons & 1 & 0.2 & 0.3 & $O-M P-B P$ & Williams \& McEldowney (1990) \\
\hline Unidentified fish & 27 & 5.2 & 8.1 & - & - \\
\hline Crustaceans (total) & (211) & $(40.4)$ & $(63.0)$ & - & - \\
\hline Euphausia vallentini & 126 & 24.2 & 37.6 & O-EP & Brinton \& Antezana (1981) \\
\hline Themisto gaudichaudii & 71 & 13.5 & 23.0 & O-EP & Kane (1966) \\
\hline Unidentified crustaceans & 14 & 2.7 & 4.2 & - & - \\
\hline Cephalopods (total) & (82) & $(15.8)$ & $(24.5)$ & - & - \\
\hline Martialia hyadesi & 77 & 14.8 & 23.0 & O-MP & Nesis (1987) \\
\hline Gonatus antarcticus & 1 & 0.2 & 0.3 & O-MP & Nesis (1987) \\
\hline Onychoteuthid & 1 & 0.2 & 0.3 & - & - \\
\hline Unidentified cephalopods & 3 & 0.6 & 0.9 & - & - \\
\hline
\end{tabular}




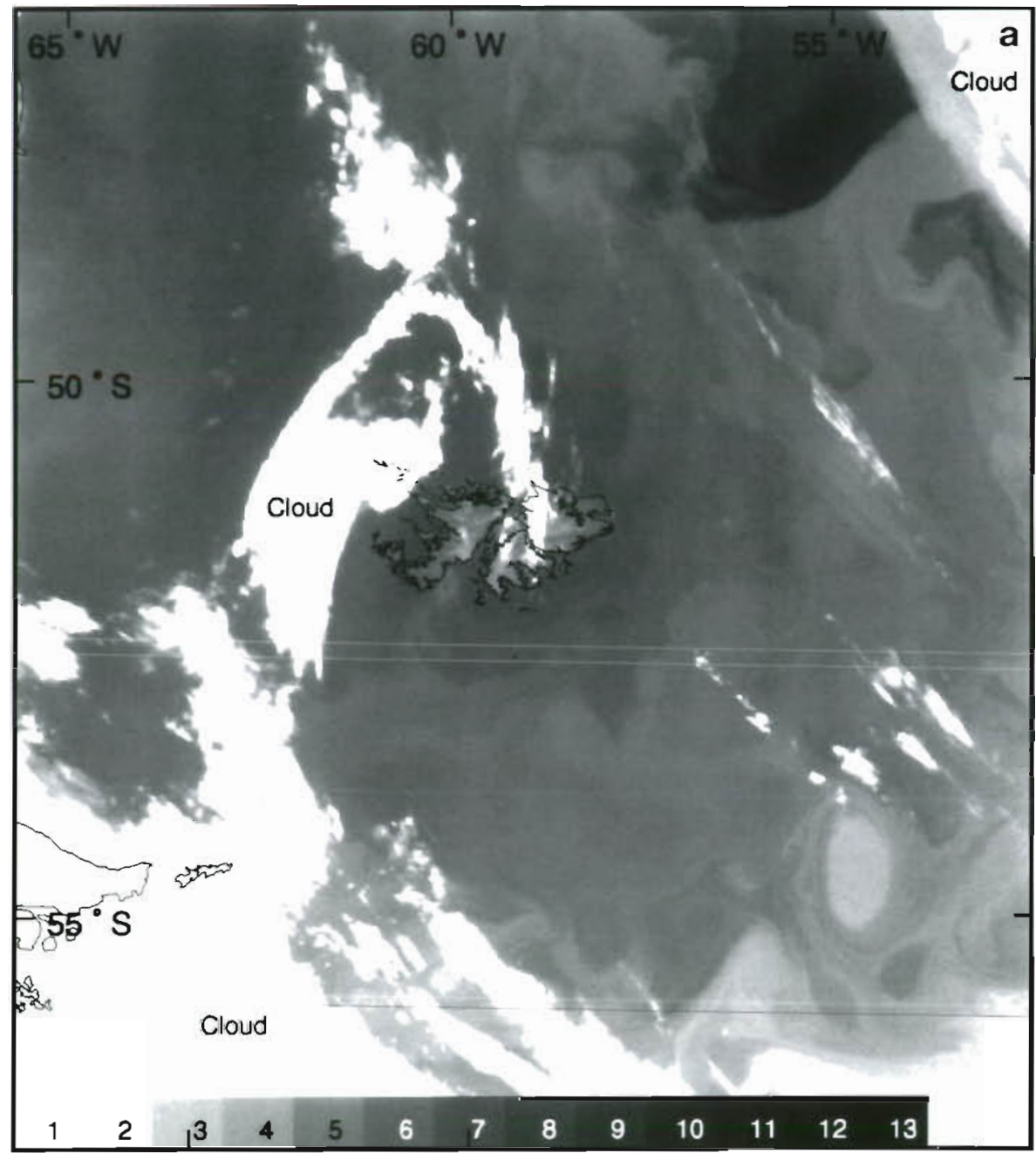

Fig. 9. (a) Remotely sensed, in frared (sea surface temperature) image of the Patagonian Shelf and oceanic region around the Falklands Islands, capture at $09: 30 \mathrm{~h} \mathrm{Z}$ on 21 April 1995: taken from the ARIES (Antarctic Reception of Imagery for Environmental Studies database $_{i}(b)$ Traced land masses, bathymetry and isotherms illustrating surface oceanography including mesoscale features at the Patagonian Shelf edge north of the Falkland Islands. (Position where the historical SST OI data set was extracted is indicated by an arrow

between positive and negative anomalies, some 4 to 15 mo after a positive and 6 to 10 mo before a negative anomaly.

\section{Teleconnections with large-scale oceanographic variability}

SST anomaly data (NCAR Data Center, Boulder, Colorado, USA) from the eastern Pacific Ocean $0^{\circ}$ to $10^{\circ} \mathrm{S}$, $80^{\circ}$ to $90^{\circ} \mathrm{W}$ show the warm ENSO events of $1982 / 83$, 1987 and 1992 (Fig. 10) which were followed by cold, La Niña events in 1985, 1988 and 1994/95. The recent La Niña event. which has continued into 1996, has been associated with a dramatic reduction in catches of the ommastrephid Dosidicus gigas (jumbo flying squid) in the Peruvian fishery (Yamashiro et al. in press) and it is perhaps noteworthy that the 1986 , $1989 / 90$ and 1995 'Martialia hyadesi events' in the South Atlantic followed the cold, La Niña events in the eastern Pacific. Warm events in the South Atlantic fol-

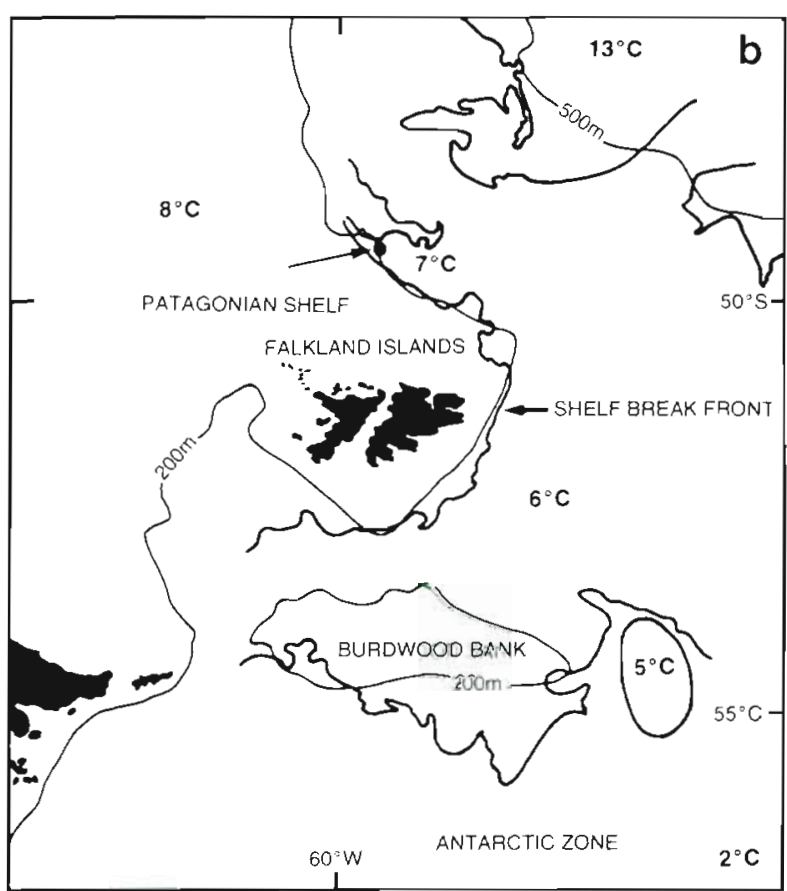



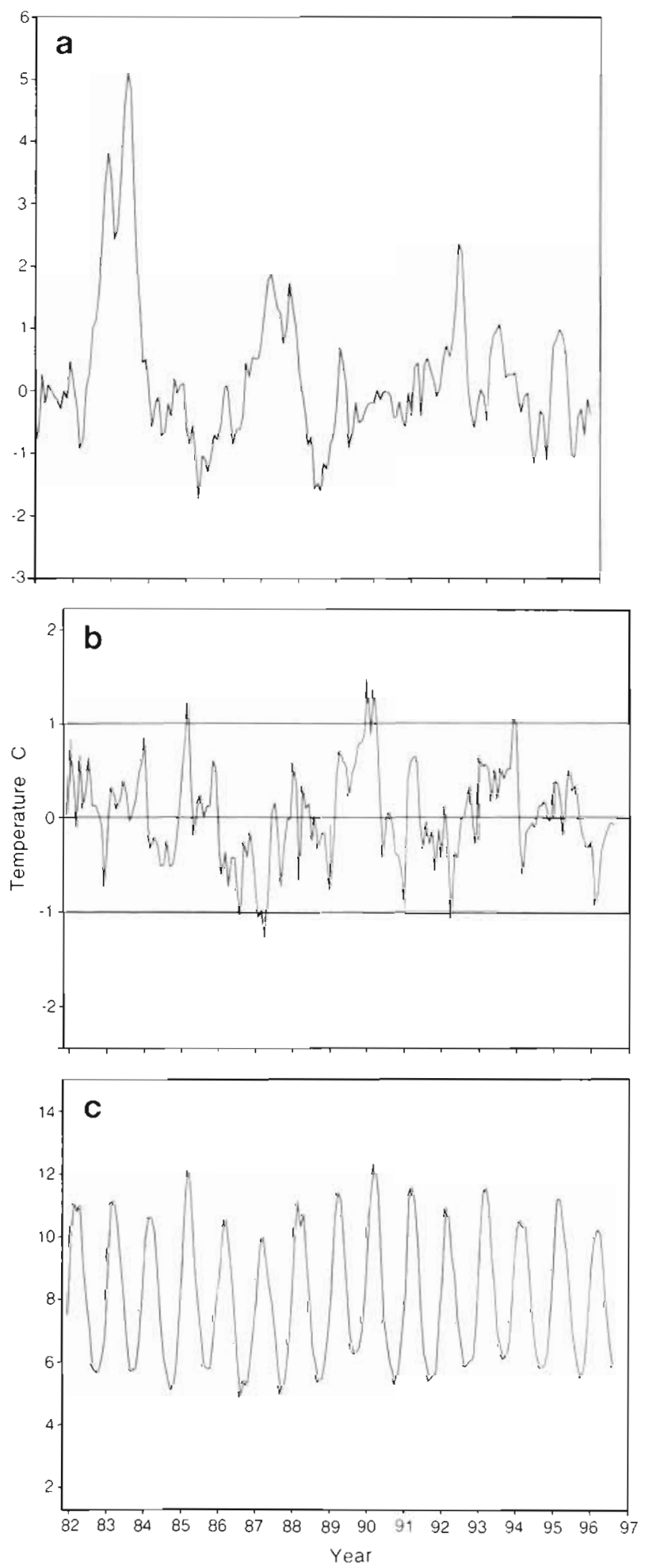

Fig. 10. (a) Sea surface temperature anomaly data (NCAR Data Center, Boulder, Coloradol from the eastern Pacific Ocean $0^{\circ}$ to $10^{\circ} \mathrm{S}, 80^{\circ}$ to $90^{\circ} \mathrm{W}$. (b) Monthly anomalies (upper and lower horizontal lines indicate \pm 2 standard deviations) and (c) monthly sea surface temperature optimum interpolation (SST OI) time series between November 1981 and July 1996 for the grid cell $59^{\circ} 30^{\prime} \mathrm{W}, 49^{\circ} 30^{\prime} \mathrm{S}$ (tuc marks indicate beginnung of year labelled; data set in (a) commences 1 yr earlier) low some 24 to 30 mo after those in the Pacific and cold events in the South Atlantic follow some 12 to 24 mo after those in the Pacific.

The interval between warm and cold SST anomalies in the middle panel of Fig. 10 also approximate the 4 to $5 \mathrm{yr}$ period of the Antarctic circumpolar wave (ACW) in several physical variables described by White \& Peterson (1996) and which relate to the circumpolar precession of anomalous sea ice extent in the Antarctic (Murphy et al. 1995).

\section{DISCUSSION}

Over the last decade Martialia hyadesi has appeared on the edge of the southern Patagonian Shelf in sufficient numbers to generate a fishery on 3 occasions. The data for the 1995 fishery indicate that there is no evidence that $M$. hyadesi makes significant incursions over the shelf, remaining largely outside the $250 \mathrm{~m}$ contour in the cool APFZ waters of the Falkland Current. Here $M$. hyadesi preys on macroplanktonic/micronektonic members of the oceanic mesopelagic and epipelagic community. Variability in the distribution of $M$. hyadesi may therefore be related to variability in the oceanic system off the shelf edge.

A profile of the population from the 1995 fishery in the FICZ/FOCZ indicates that the squid appeared in the fishery at an age of about 6 to 12 mo when feeding, growing and maturing, but when females were still at an early stage of maturity. Male Martialia hyadesi, in common with Illex argentinus (Rodhouse et al. 1995), mature earlier than females and, judging from sex ratios, are partially segregated from females during the exploited phase of the life cycle.

The normal life span of Martialia hyadesi in the South Atlantic remains to be fully resolved. Our data seem to be consistent with a 2 yr life cycle assuming some reduction in growth rate towards the end of the 2 yr. Although no large, mature female specimens were recorded in the 1995 fishery, mature specimens of large size have occasionally turned up in the Falklands fishery in recent years. It is not known, however, whether these represented a distinct cohort of large, mature squid which would indicate a different year class. There was no evidence of bimodality in the 1995 data or in earlier data (Rodhouse 1991, Rodhouse et al. 1994). Large, mature squid are apparently not generally available to the fishery as it operates in the South Atlantic. In common with other ommastrephids, growth patterns of $M$. hyadesi are probably variable and plastic and further data on life span and growth are needed to clarify the picture.

In common with Illex argentinus in the South Atlantic (Haimovici et al. in press), peak hatching time 
for the Martialia hyadesi population, sampled by the fishery in summer, is the austral winter of the previous year. Presumably winter spawning has evolved in both species to optimise the match between timing of the critical paralarval and juvenile phases with seasonality in the plankton. The observations of mature females, coupled with the records of small numbers of posthatching juveniles on the Patagonian Shelf edge (Rodhouse et al. 1992a), show that some spawning takes place in the vicinity of the Falkland Islands. Knowledge of the life cycle of $M$. hyadesi is incomplete and information is particularly needed on the latter part of the life cycle, on spawning biology and paralarval, juvenile and pre-recruitment biology.

In 1995 concentrations of exploited Martialia hyadesi were associated with mesoscale oceanographic features on the shelf break front separating shelf water from the APFZ water of the Falkland Current. This front is a region of high primary and secondary productivity supporting several squid and fish stocks (Bertolotti et al. 1996). Association of $M$. hyadesi with mesoscale frontal processes is consistent with behaviour observed in the APFZ to the north of South Georgia (Rodhouse et al. 1996).

The behaviour of the Martialia hyadesi stock over the decadal time scale represented by FIG Fisheries Department data, Japanese catch data and catches reported to FAO and the SST OI analysis reveals apparent links with environmental variability. Catch rates (Fig. 2) suggest a relationship with anomalies in the oceanographic regime which are likely to be linked to large-scale variability such as ENSO and the ACW.

The large-scale SST OI data integrate the mesoscale spatial and temporal variability in the region so that large-scale patterns remain evident (Fig. 10). The mechanism by which seasonal and interannual variability in the regional oceanography affects the Martialia hyadesi stock is not understood. Oceanographic variability could affect the population during one or more of a number of critical periods, for example altered hydrographic conditions may affect the stock during egg development, hatching, juvenile development, migration, sexual maturation, or spawning. Furthermore, such effects may be more important during the life span of the parent generation, rather than that of the current generation. Such effects may occur at a place or time remote from where and when the squid are exploited. Considering the potential mobility of $M$. hyadesi, environmental influences may be exerted in areas remote from the Falklands Plateau.

Given the occurrence of 'Martialia hyadesi events' between warm and cold anomalies in the South Atlantic, 2 hypotheses are suggested. Firstly, warm conditions preceding the appearance of the squid may favour the reproductive success of the parent genera- tions or the early life cycle stages of the generations which recruit. Alternatively, $M$. hyadesi, which is associated with the cool waters of the A.PFZ, may recruit in exceptional numbers into the region near the Patagonian Shelf edge during the phase preceeding a cold anomaly. This would represent the reverse situation to that described by Dawe \& Warren (1993) for Illex illecebrosus in the northwest Atlantic which is a relatively warm-water species that is adversely affected by cold events associated with the Labrador Current The 2 hypotheses for variability in $M$. hyadesi in the South Atlantic are not mutually exclusive and could be tested by comparative studies if there were more information on the life cycle.

Knowledge of relations between ommastrephid squid populations, their food and mesoscale oceanographic features, and of the links between the dynamics of these mesoscale features and large-scale oceanographic variability (whether manifested as ENSO events or the ACW) would greatly assist in understanding the variability in short-lived squid populations that respond rapidly to environmental change. Understanding these links might in turn assist shortterm forcasting of catch levels in the fisheries for these notoriously unpredictable, but increasingly valuable, invertebrate resources.

Acknowledgements. We thank J. Barton, N. Buxton, Z. Cielniaszek, R. Coggan, M. George and C. Nolan (FlG Fishenes Department) for their collaboration, E. Hatfield, E. Murphy, K. Reid and M. White (BAS) for help and advice, A. Guerra (Instituto de Investigaciones Marinas, Vigo) for use of image analysis facilites, D. Agnew (Imperial College for Science and Technology) for reading a draft, A. Johnson (Boyd Line Ltd) for answering numerous telephone enquiries about the South Atlantic fishing industry, S. Masutomi and S. Machida (KSJ Corporation, Japan) for early Japanese catch data, K. Yokawa (National Research Institute for Far Seas Fisheries, Japan) for recent Japanese catch data and G. Tarling (Dunstaffnage Marine Laboratory) for identifying crustaceans in the gut contents of squid. The research forms part of the Pelagic Ecosystems Studies programme within the Marine Life Sciences Division of the British Antarctic Survey. A.F.G. was supported by the Spanish Ministerio de Educacion y Ciencia.

\section{LITERATURE CITED}

Bertolotti MI, Brunetti NE, Carreto JI, Prenzki LB, Sanchez RP (1996) Influence of shelf-break fronts on shellfish and fish stocks off Argentina. ICES C.M. 1996/S:41

Brinton E, Antezana T (1981) Euphausiacea. In: Boltovskoy D (ed) Atlas del Zooplancton del Atlántico Occidental. Publ esp INIDEP, Mar del Plata, p 681-694

Clarke MR (1986) A handbook for the identification of cephalopod beaks. Clarendon Press, Oxford

Croxall JP, McCann TS, Prince PA, Rothery P (1988) Reproductive performance of seabirds and seals at South Georgia and Signy Island, South Orkney Islands, 1976-1987: implications for Southern Ocean monitoring studies. In: 
Sahrhage D (ed) Antarctic Ocean and resources variability. Springer-Verlag, Berlin

Davis RE, Killworth PD, Blundell JR (1996) Comparisons of Autonomous Lagrangian Circulation Explorer and fine resolution Antarctic model results in the South Atlantic. J Geophys Res 101:855-884

Dawe EG, Natsukari Y (1991) Light microscopy. In: Jereb P, Ragonese S, Boletzky SV (eds) Squid age determination using statoliths. Proceedings of the International Statolith Workshop held in The Instituto di Tecnologia della Pesca e del Pescato. ITPP Special publication, p 83-95

Dawe EG, Warren WG (1993) Recruitment of short-finned squid in the northwest Atlantic Ocean and some environmental relationships. J Ceph Biol 2:1-21

FAO (1994) Yearbook of fishery statistics. Catches and landings. Vol 77. FAO, Rome

Garzoli SL, Garrafo Z (1989) Transports, frontal motions and eddies at the Brazil-Malvinas Currents Confluence. Deep Sea Res 36:681-703

Haimovici M, Brunetti NE, Rodhouse PG, Csirke J, Leta RH (in press) Illex argentinus. In: Rodhouse PG, Dawe EG, O'Dor RK (eds) Squid recruitment dynamics. FAO Fishenes Technical Paper. FAO, Rome

Hecht T (1987) A guide to the otoliths of Southern Ocean fishes. S Afr J Antarct Res 17(1):1-87

Ikeda Y, Siedler G, Zwierz M (1989) On the variability of Southern Ocean front locations between Brazil and the Antarctic Peninsula. J Geophys Res 94:4757-4762

Kane JE (1966) Distribution of Parathemisto gaudichaudii (Guer.), with observations on its life history in the $0^{\circ}$ to $20^{\circ} \mathrm{E}$ sector of the Southern Ocean. Discovery Rep 34: $165-197$

Legeckis R, Gordon AL (1982) Satellite observations of the Brazil and Falkland currents-1975 to 1976 and 1978. Deep Sea Res 29:375-401

Lipiński M (1979) Universal maturity scale for the commercially important squids. The results of maturity classification of Illex illecebrosus for the years 1973-1977. ICNAF Res Doc 79/1L/38 Ser 5364

Murphy EJ, Clarke A, Symon C, Priddle J (1995) Temporal variation in Antarctic Sea-ice: analysis of a long term fastice record from the South Orkney Islands. Deep Sea Res 42:1045-1062

Nesis KN (1987) Cephalopods of the world. T.F.H. Publications Inc, Neptune City, NJ

Olson DB, Podestá GP, Evans RH, Brown OB (1988) Temporal variations in the separation of Brazil and Malvinas Currents. Deep Sea Res 35:1971-1990

Peterson R, Whitworth T (1989) The Subantarctic and Polar Fronts in relation to deep water masses through the Southwestern Atlantic. J Geophys Res 94(C8):10817-10838

Priddle J, Croxall JP, Everson 1, Heywood RB, Murphy EJ, Prince PA, Sear CB (1988) Large-scale fluctuations in distribution and abundance of krill-a discussion of possible causes. In: Sahrhage D (ed) Antarctic Ocean and resources variability. Springer-Verlag, Berlin, p 169-182

Reid K (1996) A guide to the use of otoliths in the study of predators at South Georgia. British Antarctic Survey, Cambridge, ii

Reynolds RW. Smith TM (1994) Improved global sea surface

This article was submitted to the editor temperature analyses using optimum interpolation. J Clim Res 7:929-948

Rodhouse PG (1991) Population structure of Martialia hyadesi (Cephalopoda: Ommstrephidae) at the Antarctic Polar Front and the Patagonian shelf, South Atlantic. Bull Mar Sci 49:404-418

Rodhouse PG (in press) Precautionary measures for a new Martialia hyadesi (Cephalopoda, Ommastrephidae) fishery in the Scotia Sea: an ecological approach. CCAMLR Sci

Rodhouse PG, Barton J, Hatfield EMC, Symon C (1995) Illex argentinus: life cycle population structure and fishery. ICES Mar Sci Symp 199:425-432

Rodhouse PG, Croxall JP, Prince PA (1993) Towards an assessment of the stock of the ommstrephid squid Martialia hyadesi in the Scotia Sea: data from predators. In: Okutani $T$, O'Dor RK, Kubodera $T$ (eds) Recent advances in cephalopod fisheries biology. Tokai University Press, Tokyo, p $433-444$

Rodhouse PG, Hatfield EMC (1990) Dynamics of growth and and maturation in the cephalopod Illex argentinus de Castellanos, 1960 (Teuthoidea: Ommastrephidae). Phil Trans R Soc Lond Ser B 329:229-241

Rodhouse PG, Prince PA, Trathan PN, Hatfield EMC, Watkins DG, Bone DG, Murphy EJ, White MG (1996) Cephalopods and mesoscale oceanography at the Antarctic Polar Front: satellite tracked predators locate pelagic trophic interactions. Mar Ecol Prog Ser 136:37-50

Rodhouse PG, Robinson K, Gajdatsy SB, Daly HI, Ashmore MJS (1994) Growth, age structure and environmental history in the cephalopod Martialia hyadesi (Teuthoidea: Ommstrephidae) at the Antarctic Polar Frontal Zone and on the Patagonian Shelf Edge. Antarct Sci 6(2):259-267

Rodhouse PG, Symon C. Hatfield EMC (1992a) Early life cycle of cephalopods in relation to the major oceanographic features of the southwest Atlantic Ocean. Mar Ecol Prog Ser 89:183-195

Rodhouse PG, White M (1995) Cephalopods occupy the ecological niche of epipelagic fish in the Antarctic Polar Fronal Zone. Biol Bull (Woods Hole) 189:77-80

Rodhouse PG, White MG, Jones MRR (1992b) Trophic relations of the cephalopod Martialia hyadesi (Teuthoidea: Ommstrephidae) at the Antarctic Polar Front, Scotia Sea. Mar Biol 114:415-421

Rodhouse PG, Yeatman J (1990) Redescription of Martialia hyadesi Rochebrune and Mabille, 1889 (Mollusca, Cephalopoda) from the Southern Ocean. Bull Br Mus (Nat Hist\} Zool Suppl 56:135-143

Trathan PN, Murphy EJ, Symon CJ, Rodhouse PG (1993) Ecological and oceanographic relationships in the Southern Ocean. GIS Europe 2:34-36

White BW, Peterson RG (1996) An Antarctic circumpolar wave in surface pressure, wind, temperature and sea-ice extent. Nature 380:699-702

Williams R, McEldowney A (1990) A guide to the fish otoliths from waters off the Australian Antarctic Territory. Heard and Macquarie Islands. ANARE (Aust Natl Antarct Res Exped) Res Notes 75:1-173

Yamashiro C, Mariategui L, Arguelles J, Tafur R, Rabi M (in press) Proceedings of the JAMARC 25 Anniversary Symposium, Tokyo, July 1996

Manuscript first received: January 6, 1997

Revised version accepted: April 21, 1997 